\title{
Training Mode of Compound Talents in Business Administration Major under the Background of Innovation and Entrepreneurship
}

\author{
Xingle Teng \\ Business School, Shandong University of Technology \\ Zibo, China \\ Email: 1751205977 [AT] qq.com
}

\begin{abstract}
In the context of dual innovation, the traditional business management personnel training model has been unable to adapt to the market demand in the new economic environment. It is increasingly important for universities to integrate the resources outside the school and gradually explore and form a new model for cultivating innovative and entrepreneurial talents. This paper explores this issue from the aspects of curriculum system construction, teaching staff construction and teaching mode reform, in order to provide reference for the cultivation of business management talents.
\end{abstract}

Keywords--- Compound Talent, Business Administration Major, innovation

\section{INTRODUCTION}

Since the establishment of the major of business management in 2002,our school has graduated more than 1500 undergraduates in 15 yearse.We have successively obtained the master of enterprise management(2016),MBA(2010) and master'point of first-level business admin stration(2018). Graduates of this major have achieved high social satisfaction.The employment rate of undergraduates in 2018 is $94.44 \%$, that in 2017 is $96.52 \%$, and in 2016 it is $96.69 \%$. Many graduates have become the industry elite,and many students have been admitted to graduate shool to continue their studies and become research backbone of well-known universities.

\section{WORK BASE}

The professional orientation is to deeply connect the old and new kinetic energy conversion to serve the high-quality development of regional economy.Focusing on the integration of industry and education to improve students' ability of innovation and entrepreneurship, we will implement the training mode of applied, compound and innovative business management talents.Through the teaching conditions ,teaching staff , the differentiated and characteristic development of collaborative education, efforts will be made to cultivate five talented people and build a first-class and influential undergraduate major in business administration in the province.To this end, we have mainly done the following four aspects of work.

\section{The reform of thinking mode of teachers and students}

In the face of the new situation, it is necessary to change the thinking mode of teachers and students in order to cultivate talents that are suitable for the needs of society.First of all, teachers should change their thinking mode. At present, the mainstream idea of education is still what teachers teach and what students learn in the classroom. But in the environment of promoting double innovation, the school began to promote innovation and entrepreneurship from top to bottom,constantly urging teachers to learn new educational concepts and keep up with changes in the environment.Secondly,to cultivate students' entrepreneurial awareness, the key to entrepreneurship is to have entrepreneurial awareness. Through the participation of students in Entrepreneurship design and practice, we can cultivate students'emotions about entrepreneurship, make students interested in entrepreneurship, and let students always have strong enthusiasm and belief in entrepreneurship practice activities.

\section{Curriculum system construction}

We have revised the curriculum system. Focusing on innovative entrepreneurship courses, curriculum modules are organized, and teaching teams are formed to prepare lessons collectively. According to the specific situation of business administration, the concept of entrepreneurship is combined with the curriculum. In the course system of entrepreneurship education, courses of entrepreneurship, knowledge of entrepreneurship management, quality of entrepreneurship ability and practical operation of entrepreneurship are added. While improving students'professional management knowledge, the basic knowledge and ability of traditional management are combined with the curriculum of 
entrepreneurship education. The combination of innovation and entrepreneurship knowledge and ability is more conducive to the improvement of students'entrepreneurship quality and ability, and also to promote the improvement of Business Administration curriculum system. At the same time, we have revised the evaluation system. In view of the characteristics of strong practicality of business administration major, the reform of assessment methods is promoted and the strength of practical assessment is increased.In the aspect of theoretical assessment, the separation of teaching and examination, the establishment of examination question bank by different specialties and the unified flow marking are implemented; in the aspect of practical assessment, the combination of process control and result assessment is emphasized, and detailed assessment criteria are formulated to ensure the rationality and accuracy of the assessment.

\section{Teaching staff construction}

Excellent faculty is an important part of cultivating talents.According to the mode of "strict introduction, recultivation and mutual employment", we should vigorously promote the construction of double-qualified teaching team, and precisely introduce senior professional titles and high-quality middle-aged teachers with rich experience in enterprise management. Efforts should be made to train excellent young doctorates who have both overseas study and practical experience in enterprises. Active external entrepreneurs and venture capitalists are enterprise mentors. Teachers'team building has gradually achieved remarkable results.In 2018, four of our teachers were awarded the qualification certificate of entrepreneurship mentor, 20 of them were employed, and one of them was named a famous teacher of school-level teaching, which laid a solid foundation for professional construction.

\section{Teaching mode reform}

In the teaching of undergraduate students of business administration, we have changed the traditional teaching mode which emphasizes theory teaching but ignores practice.We are setting up a new teaching mode with the core of cultivating students'practical and innovative abilities as well as the ability of researching and solving problems.Firstly, experimental links should be added. Through experiments, students can rise from theory to practice. For example, we train students to use software to simulate the operation of enterprise decision-making.In addition, teachers can conduct sandbox simulations in the classroom, combined with market changes and role-playing, so that students can experience the entrepreneurial process in a virtual market competition environment.Secondly, strengthen school-enterprise cooperation.We have set up the internship course of enterprise cognition, through which teachers can lead students to visit production-oriented enterprises and other enterprises to improve students' perceptual understanding, so that students can have a deeper understanding of all theoretical knowledge.Thirdly, relying on the entrepreneurial base established by the school, it provides a platform for students'entrepreneurial practice. With the help of internal practice platform, students are guided to participate in the entrepreneurship contest and have achieved good results.

\section{CONSTRUCTION OBJECT}

Focusing on the transformation of new and old kinetic energy, in order to achieve the goal of "Five" talents training, this professional innovative talent training model hopes to build a compound talent training system featuring broad foundations of business administration and innovation and entrepreneurship in the next few years. Efforts should be made to achieve win-win results among students, schools and enterprises.

\section{REFERENCES}

[1] SU J Q,JIA Y B.The Research Status, Application Prospects and Contextualized Depth of Case Studies of Business Administration in China[J].[2]Chinese Journal of Management,2018,15(06),791-802.

[2] Luo Qian-wen.Research on Practical Teaching Reform of Applied Business Administration Major Based on the Cultivation of Innovation and Entrepreneurship[J].Journal of Beijing College of Finance and Commerce,2018,34(05),42-45.

[3] CHEN Ch b,SHENG X.Establishment of the Resources of the Core Curriculum about Business Management Specialty:Based on the Integration of Innovation and Practice Perspective[J].Value Engineering,2018,37(15),273276.

[4] CHENG Y Y, LIU CH X.Research on the Cultivation of Applied Talents in the Major of Business Administration in Local Universities[J].Journal of Qiqihar University( Phi \& Soc Sci) Jan.2019(1). 